\title{
Antibacterial activities of Beilschmiedia obscura and six other Cameroonian medicinal plants against multi-drug resistant Gram-negative phenotypes
}

\author{
Aimé G Fankam, Jules R Kuiate and Victor Kuete*
}

\begin{abstract}
Background: The rapid spread of bacteria expressing multi-drug resistance propels the search for new antibacterial agents. The present study was designed to evaluate the antibacterial activities of the methanol extracts from Beilschmiedia obscura and six other Cameroonian plants against a panel of twenty nine Gram-negative bacteria including Multi-drug resistant (MDR) phenotypes.

Methods: The phytochemical investigations of the extracts were carried out according to the standard methods and the liquid micro-dilution assay was used for all antibacterial assays.

Results: Phytochemical analysis showed the presence of alkaloids in all studied extracts. Other chemical classes of secondary metabolites such as anthocyanines, anthraquinones flavonoids, saponins, tannins, sterols and triterpenes were selectively detected in the extracts. The extract from the fruits of Beilschmiedia obscura, Pachypodanthium staudtii leaves and Peperomia fernandopoiana (whole plant) displayed the best spectrum of activity with MIC values ranging from 16 to $1024 \mu \mathrm{g} / \mathrm{mL}$ against at least 65\% and above of the tested bacteria. The extract from Beilschmiedia obscura was the most active with MIC values below $100 \mathrm{\mu g} / \mathrm{mL}$ against ten of the tested bacteria. This extract also showed MBC values below $1024 \mathrm{\mu g} / \mathrm{mL}$ against $55.17 \%$ of the studied microorganisms. Phenylalanine arginine $\beta$-naphthylamide (PABN) significantly modulated the activities of extracts from the leaves and fruits of Pachypodanthium staudtii and Beilschmiedia obscura respectively, by increasing their inhibitory activity against Klebsiella pneumoniae KP55 strain at least four fold.

Conclusion: The overall results of the present investigation provide information for the possible use of the methanol extracts of the studied plant species, especially B. obscura to fight infectious diseases caused by Gram-negative bacteria including MDR phenotypes.
\end{abstract}

Keywords: Antibacterial activity, Beilschmiedia obscura, Gram-negative bacteria, Multi-drug resistance, Efflux pumps, Medicinal plants

\section{Background}

Bacterial chemo-resistance is a worrisome health concern worldwide today [1-3]. The development of multi-drug resistant (MDR) bacteria has severely compromised the efficacy of antimicrobial weapons and has dramatically increased the frequency of therapeutic failure [4]. Several reports highlighted the increased hospital dissemination of the bacterial strains expressing drug efflux mechanism

\footnotetext{
* Correspondence: kuetevictor@yahoo.fr

Department of Biochemistry, Faculty of science, University of Dschang, P.O. Box 67, Dschang, Cameroon
}

[5,6]. Among the known efflux mechanisms of resistances in Gram-negative bacterial strains, Resistance-Nodulationcell Division (RND) pump is one of the most occurring systems [7]. A number of chemicals such as phenylalanine arginine $\beta$-naphthylamide (PA $\beta \mathrm{N}), 1$-(1-naphthylmethyl)piperazine, some quinolone derivatives $[8]$ as well as some natural products like reserpine [9] have been found to inhibit bacteria efflux pumps. The problem of bacterial resistance to commonly used antibiotics then shifted attention towards the discovery of new natural antibacterial compounds. Plants commonly used as herbal medicine 
may be a source of antibacterial, antifungal and antiviral activities [10-12]. In Cameroon, there is a rich tradition of using medicinal plants for the treatment of various infectious diseases, inflammations, injuries, and other diseases $[13,14]$. The aim of the investigation was to determine the antibacterial effects of twelve methanol crude extracts belonging to seven Cameroonian medicinal plants namely Peperomia fernandopoiana C.DC. (Piperaceae); Cinchona succirubia Par. Ex Klotzsk. (Rubiaceae), Pachypodanthium staudtii Engl \& Diels (Annonaceae), Vepris soyauxii Engl. (Rutaceae), Crassocephalum biafrae (Oliv. \& Hiern) S. Moore; Beilschmiedia obscura (Staph). Engl. (Lauraceae) and Entada gigas (Linn) Fawcelt \& Rendle (Mimosaceae) against a panel of MDR Gram-negative bacteria expressing active efflux pumps. Most of these plant species or their related genus are known for their antimicrobial properties (Table 1). The role of efflux pumps was also investigated using pump-deleted bacteria and the efflux pump inhibitor (EPI) PA $\beta \mathrm{N}$.

\section{Methods}

\section{Plant materials and extraction}

All medicinal plants used in the work were collected in different areas of Cameroon between January and April 2012. The plants were identified at the National Herbarium (Yaounde, Cameroon), where voucher specimens were deposited under the reference numbers (Table 1). The airdried and powdered plant material was weighed (300 g) and soaked in $1 \mathrm{~L}$ of methanol $(\mathrm{MeOH})$ for $48 \mathrm{~h}$ at room temperature. The filtrate obtained through Whatman filter paper No1was concentrated under reduced pressure in a vacuum to obtain the crude extracts. All crude extracts were kept at $4^{\circ} \mathrm{C}$ until further uses.

\section{Preliminary phytochemical investigations}

The plant extracts were screened for the presence of major secondary metabolite classes such as alkaloids, anthocyanins, anthraquinones, flavonoids, phenols, saponins, sterols and triterpenes according to common phytochemical methods previously described by Harbone [38].

\section{Chemicals}

Chloramphenicol (CHL) (Sigma-Aldrich, St Quentin Fallavier, France) was used as reference antibiotic (RA). $p$ Iodonitrotetrazolium chloride (INT) and phenylalanine arginine $\beta$-naphthylamide (PA $\mathrm{NN}$ ) (Sigma-Aldrich) were used as bacteria growth indicator and efflux pumps inhibitor (EPI) respectively.

\section{Bacterial strains and culture media}

MDR isolates (Laboratory collection) and reference strains (from the American Type Culture Collection: Escherichia coli ATCC8739 and ATCC10536; Enterobacter aerogenes ATCC13048; Klebsiella pneumoniae ATCC11296; and
Providencia stuartii ATCC29916) of Escherichia coli, Enterobacter aerogenes, Klebsiella pneumoniae, Enterobacter cloacae, Pseudomonas aeruginosa, and Providencia stuartii were used. Their features were previously reported $[39,40]$. They were maintained at $4^{\circ} \mathrm{C}$ and sub-cultured on a fresh appropriate Mueller Hinton Agar (MHA) for $24 \mathrm{~h}$ before any antibacterial test.

\section{Microdilution assay for MIC and MBC determinations}

The microdilution inhibitory concentration (MIC) of the seven plant extracts and chloramphenicol were determined using a rapid microdilution assay [41,42]. Briefly, the samples were first dissolved in $10 \%$ dimethyl sulfoxide (DMSO)/Mueller Hinton Broth (MHB). The solution obtained was then added to MHB and serially diluted two fold (in a 96-well microplate). One hundred microliters of inoculum $\left(1.5 \times 10^{6} \mathrm{CFU} / \mathrm{mL}\right)$ prepared in MHB were then added. The plates were covered with a sterile plate sealer and then agitated with a shaker to mix the contents of the wells and incubated at $37^{\circ} \mathrm{C}$ for $18 \mathrm{~h}$. The final concentration of DMSO was less than 2.5\%, and did not affect the microbial growth. Wells containing MHB, $100 \mu \mathrm{l}$ of inoculum, and DMSO at a final concentration of $2.5 \%$ served as the negative control. The MIC of each sample was detected after $18 \mathrm{~h}$ of incubation at $37^{\circ} \mathrm{C}$ following addition of $40 \mu \mathrm{l}$ INT $(0.2 \mathrm{mg} / \mathrm{mL})$ and incubation at $37^{\circ} \mathrm{C}$ for $30 \mathrm{~min}$. The $\mathrm{MIC}$ was defined as the lowest sample concentration that prevented color change of the medium and that resulted in the complete inhibition of bacterial growth [43]. Viable bacteria reduced the yellow dye to a pink. The minimum bactericidal concentration $(\mathrm{MBC})$ of the sample was determined by sub-culturing $50 \mu \mathrm{l}$ of the suspensions from the wells which did not show any growth after incubation during MIC assays to $150 \mu \mathrm{l}$ of fresh broth, and re-incubated at $37^{\circ} \mathrm{C}$ for 48 hours before re-evaluation. The MBC was defined as the lowest concentration of sample which completely inhibited the growth of bacteria $[44,45]$. Each assay was performed in three independent tests in triplicate.

The tested samples, the samples were also tested in the presence of PA $\beta N$ at a final concentration of $20 \mu \mathrm{g} / \mathrm{mL}$ as previously described [46] against nine of the most resistant bacteria strains. The MIC was determined as described above.

\section{Results}

Phytochemical composition of the plant extracts

The results of the qualitative phytochemical analysis indicated that alkaloids were present in all plant extracts. Each of the studied plant extract contained at least two classes of secondary metabolites (Table 2).

\section{Antibacterial activity of the plant extracts}

The data depicted in Table 3 show that all extracts were active on at least two bacterial strains with MIC values 
Table 1 Plants used in the present study and evidence of their bioactivities

\section{Traditional treatmen}

Vepris soyauxii Engl. (Rutaceae) 18394 SFR/Cam

Peperomia fernandopoiana C.DC (Piperaceae); 7171 SRF/Cam

Pachypodanthium staudtii Engl \& Diels (Annonaceae), 23170 SFR/ Cam

Crassocephalum biafrae (Oliv. et Hiern) S.Moore 43562 HNC

Diabetes, pulmonary defects ([28,29]; bleeding, sore eyes, cough, heart troubles, rheumatic pain, oedemas [30] and women infertility $[31,32]$.

Bandja, Haut-Nkam; West region of Cameroon

collection information

Chest pain, tumors [18]; toothache [19]; bronchitis [20] and oedemas [21]

Ebolowa, Sud region of Cameroon
Known bioactive (or potentially active)

Fibromyomes [15], stomac ache and malaria

Microbial infections (Personal information)

Foreke-Dschang, West region of Cameroon

Rendle (Mimosaceae) 5861 SRF/

Cam

Cinchona succirubia Par. Ex Klotzsk. Malaria [35,36].

(Rubiaceae) 25851 SRF/Cam

Beilschmiedia obscura (Staph).Engl.

(Lauraceae)2102 SRFK information)

Gastrointestinal infection (persona

Dschang market, West compounds

Screened activity for crude plant extracts and bioactive compounds

Stem bark extracts reduced sex hormones and some sperm parameters in male albinos

rats [16].

ribalinin, (+)-isoplatydesinin and araliopsin [17].

Lebialem, South West

Pachypodol, 2,4,5-Trimethoxystyrene

Pachypophyllin, pachypostaudins A and B [21]; pachypodanthine [22]; Pachypophyllin and pachysontol [23]; staudin [24]; Sabinene, $\beta$-elemene, E- $\beta$-caryophyllene, $\beta$-selinene, $\beta$-bisabolene, $\delta$-cadinene, 2,4,5-trimethoxy1 -vinylbenzene [25].

Biafraecoumarins A, B, and C [33].

Foreke-Dschang, West Quinine [36] region of Cameroon

Obscurine [37]

Hexane fraction protects legume seeds from bruchid insects: Acanthoscelides obtectus Say on common bean (Phaseolus vulgaris) and Callosobruchus maculatus on cowpea (Vigna unguiculata) [26].

The flavonoid Pachypodol or 3,7,3'-tri-Omethylquercetin) showed antiviral activity against the polio-virus $[21,27]$.

Biafraecoumarins $A, B$, and $C$ exhibit low to significant antimicrobial activities against $E$. coli, B. subtilis, S. aureus, P. picketti, T. longifusus, A.flavus, M.canis, F.solani, C. albicans, and C.glabrata [33].

The evidence on the puberty onset induction and ovarian folliculogenesis effect of the aqueous extract in immature female rat have been demonstrated [34].

Evident antiplasmodial activity against chloroquine resistant Plasmodium falciparum and a total chemosuppression of parasitaemia in mice infected with Plasmodium berghei have been demonstrated [35]. 
Table 2 Extraction yields and phytochemical composition of the plant extracts

\begin{tabular}{|c|c|c|c|c|c|c|c|c|c|c|}
\hline \multirow[t]{2}{*}{ Plant samples } & \multirow{2}{*}{$\begin{array}{l}\text { Part used in } \\
\text { this study and } \\
\text { extraction } \\
\text { yield (\%) }\end{array}$} & \multicolumn{9}{|c|}{ Phytochemical composition } \\
\hline & & Alkaloids & Anthocyanines & Anthraquinones & Flavonoids & Phenols & Saponins & Tannins & Sterols & Triterpenes \\
\hline \multirow[t]{3}{*}{ Vepris soyauxii } & Leaves (6.17\%), & + & + & - & + & + & + & + & + & + \\
\hline & $\begin{array}{l}\text { Stem bark } \\
(8.58 \%)\end{array}$ & + & + & + & + & + & + & + & - & + \\
\hline & $\begin{array}{l}\text { Root bark } \\
(9.26 \%) .\end{array}$ & + & + & - & + & + & + & + & - & + \\
\hline $\begin{array}{l}\text { Peperomia } \\
\text { fernandopoiana }\end{array}$ & $\begin{array}{l}\text { Whole plant } \\
(7.28 \%)\end{array}$ & + & + & - & + & + & - & + & + & - \\
\hline $\begin{array}{l}\text { Crassocephalum } \\
\text { biafrae }\end{array}$ & $\begin{array}{l}\text { Whole plant } \\
(4.86 \%)\end{array}$ & + & - & - & - & - & - & - & + & - \\
\hline Entada gigas & Leaves (5.86\%) & + & - & - & - & + & - & + & - & - \\
\hline \multirow[t]{2}{*}{ Cinchona succirubia } & $\begin{array}{l}\text { Leaves } \\
(10.18 \%)\end{array}$ & + & - & - & + & + & - & + & + & - \\
\hline & $\begin{array}{l}\text { Stem barks } \\
(10.96 \%)\end{array}$ & + & + & + & + & + & - & + & - & - \\
\hline $\begin{array}{l}\text { Beilschmiedia } \\
\text { obscura }\end{array}$ & Fruits (3.37\%) & + & + & - & - & + & + & + & - & + \\
\hline \multirow{3}{*}{$\begin{array}{l}\text { Pachypodanthium } \\
\text { staudtii }\end{array}$} & Leaves (10\%) & + & + & + & - & + & - & + & + & - \\
\hline & $\begin{array}{l}\text { Stems bark } \\
(9.4 \%)\end{array}$ & + & + & + & + & + & - & + & + & + \\
\hline & Root (6.25\%). & + & + & + & + & + & + & + & - & + \\
\hline
\end{tabular}

(+): present; (-): absent.

varying from 16 to $1024 \mu \mathrm{g} / \mathrm{mL}$. Extracts from $P$. staudtii leaves and P. fernandopoina (whole plant) displayed the highest spectrum of activity, their inhibitory effects being observed against $72.41 \%(21 / 29)$ of the bacterial strains, followed by those from the fruits of $B$. obscura (65.52\%), stem barks of V. soyauxii, P. staudtii (55.17\%), $P$. staudtii stem bark and $V$. soyauxii leaves (51.72\%). The extract from $B$. obscura showed the best activity with MIC values below $100 \mu \mathrm{g} / \mathrm{mL}$ recorded against ten of the tested bacteria. The MIC values of this extract were lower than those of choramphenicol against $K$. pneumoniae Kp55 and E. aerogenes EA27 strains. Other extracts exhibited weak activities against a limited number of strains studied. The Bactericidal activity of the extracts was mostly noted with the extract from $B$. obscura.

Role of efflux pumps in susceptibility of Gram-negative bacteria to the tested plant extracts

When combined, PA $\beta \mathrm{N}$ modulated significantly the activities (by decreasing the MIC values at least four times) of the extract from P. staudtii leaves and B. obscura on $K$. pneumoniae Kp55 strain. Therefore, PA $\beta \mathrm{N}$ in general had little or no effects on the increase of the activities of the tested plant extracts. It improved the activity of chloramphenicol on MDR bacteria used (Table 4).

\section{Discussion}

Phytochemical composition of the plant extracts

The selective distribution of the secondary metabolites in the plant extracts may be due to the difference in the plant genus and family or the plant parts used. In fact, the presence of a particular metabolite can be influenced by the metabolisms which take place in the different plant parts. Compounds belonging to alkaloids as well as phenolics and terpenoids are well documented for their antibacterial activities [11]. Their presence in the studied extracts could therefore explain the observed activities.

\section{Antibacterial activity of the plant extracts}

Phytochemicals are routinely classified as antimicrobials on the basis of susceptibility tests that produce MIC in the range of 100 to $1000 \mu \mathrm{g} / \mathrm{mL}$ [47]. Moreover, for crude extract, antimicrobial activity is considered to be significant if MIC values are below $100 \mu \mathrm{g} / \mathrm{mL}$ and moderate when $100<$ $\mathrm{MIC}<625 \mu \mathrm{g} / \mathrm{mL}$ [11]. Therefore, the activity recorded with $B$. obscura against ten of tested bacteria strains namely E. coli (ATCC10536, AG8739, AG100, W3110), K. pneumoniae ATCC11296, KP63), E. aerogenes (ATCC13048, EA27 and EA294) and P. stuarti ATCC29916 can be considered important. If we considered the alternative criteria described by Fabry et al. [48], where extracts having MIC values below $8000 \mu \mathrm{g} / \mathrm{mL}$ have noteworthy antimicrobial activity, the overall activity recorded with most of the 


\begin{tabular}{|c|c|c|c|c|c|c|c|c|c|c|c|c|c|}
\hline \multirow[t]{3}{*}{ Bacterial strains } & \multicolumn{13}{|c|}{ Tested samples, MIC and MBC in parenthesis $(\mu \mathrm{g} / \mathrm{mL})$} \\
\hline & \multirow{2}{*}{$\begin{array}{l}\text { P. fernandopoina } \\
\text { (Whole plant) }\end{array}$} & \multicolumn{2}{|c|}{ C. succirubia } & \multicolumn{3}{|c|}{ P. staudtii } & \multicolumn{3}{|c|}{ V. soyauxii } & \multirow{2}{*}{$\begin{array}{c}\text { C. biafrae } \\
\text { (Whole plant) }\end{array}$} & \multirow{2}{*}{$\begin{array}{l}\text { B. obscura } \\
\text { (Fruits) }\end{array}$} & \multirow{2}{*}{$\begin{array}{c}\text { E. giga } \\
\text { (Leaves) }\end{array}$} & \multirow[t]{2}{*}{$\mathrm{CHL}$} \\
\hline & & Leaves & Stem bark & Leaves & Stem bark & Root & Leaves & Stem bark & Root bark & & & & \\
\hline \multicolumn{14}{|l|}{ E. coli } \\
\hline ATCC8739 & $256(-)$ & $512(-)$ & - & 1024(1024) & 1024(-) & 1024(1024) & - & $256(512)$ & $512(512)$ & - & $16(128)$ & - & 2(32) \\
\hline ATCC10536 & $512(-)$ & 1024(-) & - & $512(-)$ & - & 1024(-) & 1024(-) & 256(1024) & $512(1024)$ & 1024(-) & $32(256)$ & $1024(-)$ & $<2(32)$ \\
\hline AG100 & - & $1024(-)$ & $1024(-)$ & $512(-)$ & $1024(-)$ & $512(512)$ & $1024(-)$ & $1024(-)$ & & $1024(-)$ & $64(512)$ & - & $16(128)$ \\
\hline AG100A & $512(-)$ & $512(-)$ & - & $512(-)$ & $1024(-)$ & $512(-)$ & $1024(-)$ & - & - & $512(-)$ & $128(512)$ & $1024(-)$ & $<2(64)$ \\
\hline AG100A $A_{\text {Tet }}$ & $512(-)$ & - & - & $1024(-)$ & - & $1024(-)$ & $1024(-)$ & $512(512)$ & $1024(-)$ & - & 1024(1024) & - & $32(256)$ \\
\hline AG102 & $1024(-)$ & - & $1024(-)$ & $1024(-)$ & $1024(-)$ & - & $1024(-)$ & - & - & - & $1024(-)$ & $1024(-)$ & $32(>256)$ \\
\hline MC4100 & 1024(-) & $512(-)$ & - & $128(1024)$ & $1024(-)$ & - & $512(512)$ & $512(1024)$ & $256(1024)$ & $512(-)$ & 128(1024) & 256(1024) & $32(>256)$ \\
\hline W3110 & $512(1024)$ & $1024(-)$ & - & - & $1024(-)$ & - & $1024(-)$ & $256(1024)$ & $1024(-)$ & $1024(-)$ & $32(256)$ & $512(-)$ & $8(128)$ \\
\hline \multicolumn{14}{|l|}{ E. aerogenes } \\
\hline ATCC13048 & $-(-)$ & $1024(-)$ & - & $512(1024)$ & $1024(-)$ & - & - & $1024(-)$ & - & - & $32(256)$ & $1024(-)$ & $8(64)$ \\
\hline CM64 & $1024(-)$ & - & - & - & - & - & - & - & - & - & - & - & $>256$ \\
\hline EA27 & $1024(-)$ & - & - & $1024(-)$ & $1024(-)$ & $512(-)$ & $1024(-)$ & 1024(-) & $1024(-)$ & - & $32(512)$ & - & 64(256) \\
\hline EA3 & $1024(-)$ & $1024(-)$ & - & $1024(-)$ & - & $512(-)$ & - & - & $512(-)$ & $1024(-)$ & - & $1024(-)$ & $128(>256)$ \\
\hline EA289 & - & - & - & $1024(-)$ & - & - & - & - & - & - & - & - & $128(>256)$ \\
\hline EA298 & $1024(-)$ & - & - & $1024(-)$ & - & - & - & - & - & - & - & - & $128(>256)$ \\
\hline EA294 & $512(-)$ & $1024(-)$ & - & $256(512)$ & 1024(1024) & 1024(1024) & $512(1024)$ & $512(-)$ & - & - & $64(-)$ & - & $16(64)$ \\
\hline \multicolumn{14}{|l|}{ E. cloacae } \\
\hline ECCI69 & $1024(-)$ & - & - & - & - & - & - & - & - & - & - & - & $>256$ \\
\hline BM47 & - & - & - & - & - & - & - & - & - & - & - & - & $>256$ \\
\hline BM67 & - & - & - & - & - & - & - & - & - & - & - & $1024(-)$ & $>256$ \\
\hline \multicolumn{14}{|l|}{ K. pneumoniae } \\
\hline ATCC11296 & $256(1024)$ & $1024(-)$ & - & $256(1024)$ & $512(-)$ & 1024(1024) & $1024(-)$ & 256 (1024) & $512(1024)$ & - & 64(256) & $1024(-)$ & $4(64)$ \\
\hline KP55 & $512(512)$ & - & - & $512(1024)$ & $1024(-)$ & $512(-)$ & 1024(1024) & 1024(1024) & $512(1024)$ & $1024(-)$ & $32(128)$ & - & $64(256)$ \\
\hline KP63 & $512(-)$ & 1024(-) & - & $1024(-)$ & - & $1024(-)$ & $1024(-)$ & 1024(-) & - & $1024(-)$ & $512(1024)$ & - & $64(256)$ \\
\hline K24 & 1024(-) & - & - & - & - & - & - & - & - & - & - & - & $32(256)$ \\
\hline K2 & $512(-)$ & - & - & $512(512)$ & $512(1024)$ & $512(-)$ & $1024(-)$ & - & - & $512(-)$ & $128(1024)$ & - & $16(256)$ \\
\hline
\end{tabular}


Table 3 Minimal inhibitory concentration (MIC) and minimal bactericidal (MBC) of the plant extracts and chloramphenicol on the studied bacterial species (Continued)

\begin{tabular}{|c|c|c|c|c|c|c|c|c|c|c|c|c|c|}
\hline \multicolumn{14}{|l|}{ P. stuartuii } \\
\hline ATCC29916 & $1024(-)$ & $1024(-)$ & - & $1024(-)$ & $1024(-)$ & $512(-)$ & $1024(-)$ & $512(-)$ & $512(-)$ & $512(-)$ & 64(256) & $512(512)$ & $16(128)$ \\
\hline NEA16 & - & - & - & - & - & - & - & - & - & - & - & - & $64(256)$ \\
\hline PS2636 & 1024 & 1024(-) & - & 256(1024) & $512(-)$ & $512(-)$ & $1024(-)$ & $128(1024)$ & $512(-)$ & $1024(-)$ & $128(512)$ & - & $32(256)$ \\
\hline PS299645 & - & $1024(-)$ & - & $1024(-)$ & $1024(-)$ & $512(-)$ & - & $512(-)$ & $512(-)$ & $1024(-)$ & 128(512) & - & $32(256)$ \\
\hline \multicolumn{14}{|l|}{ P. aeruginosa } \\
\hline PA01 & $1024(-)$ & - & - & $1024(-)$ & - & 1024(1024) & - & $1024(-)$ & - & - & $1024(-)$ & $512(-)$ & $32(256)$ \\
\hline PA124 & - & - & - & - & - & - & - & - & - & - & - & - & $64(>256)$ \\
\hline
\end{tabular}

-MIC or MBC not detected at $1024 \mu \mathrm{g} / \mathrm{mL}$. (): MBC of the tested samples ( $\mu \mathrm{g} / \mathrm{mL})$. CHL: chloramphénicol. 
Table 4 MIC of tested plant extracts in the absence and presence of PA $\beta N$ against the studied bacterial strains

\begin{tabular}{|c|c|c|c|c|c|c|c|c|c|c|c|c|c|}
\hline \multirow{3}{*}{$\begin{array}{l}\text { Bacterial } \\
\text { strains }\end{array}$} & \multicolumn{13}{|c|}{ Tested samples and MIC $(\mu \mathrm{g} / \mathrm{mL})$} \\
\hline & \multirow{2}{*}{$\begin{array}{l}\text { P. Fernandopoina } \\
\text { (Whole plant) }\end{array}$} & \multicolumn{2}{|c|}{ C. succirubia } & \multicolumn{3}{|c|}{ P. staudtii } & \multicolumn{3}{|c|}{ V. soyauxii } & \multirow{2}{*}{$\begin{array}{c}\text { C. biafrae } \\
\text { (Whole plant) }\end{array}$} & \multirow{2}{*}{$\begin{array}{l}\text { B. obscura } \\
\text { (Fruits) }\end{array}$} & \multirow{2}{*}{$\begin{array}{l}\text { E. giga } \\
\text { (Leaves) }\end{array}$} & \multirow[t]{2}{*}{$\mathrm{CHL}$} \\
\hline & & Leaves & S. bark & Leaves & S. bark & Root & Leaves & S. bark & R. bark & & & & \\
\hline \multicolumn{14}{|l|}{ E. coli } \\
\hline AG100A $A_{\text {Tet }}$ & $1024(512)$ & $-(-)$ & $-(-)$ & $1024(-)$ & $-(-)$ & $1024(1024)$ & $1024(1024)$ & $512(1024)$ & $1024(1024)$ & $-(-)$ & $1024(1024)$ & $-(-)$ & $64(\leq 2)$ \\
\hline AG102 & $1024(1024)$ & $-(-)$ & $-(-)$ & $1024(1024)$ & $-(1024)$ & $-(-)$ & $1024(1024)$ & $-(1024)$ & $-(-)$ & $-(-)$ & $1024(1024)$ & $1024(1024)$ & $32(\leq 2)$ \\
\hline \multicolumn{14}{|c|}{ E. aerogenes } \\
\hline CM64 & $-(-)$ & $-(-)$ & $-(1024)$ & $-(-)$ & $-(-)$ & $-(-)$ & $-(-)$ & $-(-)$ & $-(-)$ & $-(-)$ & $-(-)$ & $-(-)$ & $>256(16)$ \\
\hline EA289 & $-(-)$ & $-(-)$ & $-(-)$ & $1024(-)$ & $-(-)$ & $-(-)$ & $-(-)$ & - (1024) & $-(-)$ & $-(-)$ & $-(-)$ & $-(1024)$ & $128(16)$ \\
\hline \multicolumn{14}{|l|}{ E. cloacae } \\
\hline ECCl69 & 1024 (1024) & - (1024) & $-(512)$ & $-(-)$ & $-(-)$ & $-(-)$ & $-(-)$ & $-(-)$ & - (1024) & $-(-)$ & $-(-)$ & $-(-)$ & $>256(128)$ \\
\hline \multicolumn{14}{|c|}{ K. pneumonia } \\
\hline KP55 & $512(512)$ & $-(-)$ & $-(-)$ & $512(128)$ & 1024 (512) & $512(256)$ & 1024 (1024) & 1024 (1024) & $512(512)$ & $1024(-)$ & $32(\leq 8)$ & $-(-)$ & $64(4)$ \\
\hline K24 & 1024 (1024) & $-(-)$ & $-(1024)$ & $-(-)$ & $-(-)$ & $-(-)$ & $-(-)$ & $-(-)$ & $-(-)$ & $-(-)$ & $-(-)$ & $-(-)$ & $32(2)$ \\
\hline \multicolumn{14}{|l|}{ P. stuartuii } \\
\hline NEA16 & $-(-)$ & $-(-)$ & $-(-)$ & - (1024) & $-(-)$ & $-(-)$ & $-(-)$ & $-(-)$ & $-(-)$ & $-(-)$ & $-(-)$ & $-(-)$ & $64(4)$ \\
\hline \multicolumn{14}{|c|}{ P. aeruginosa } \\
\hline PA124 & $-(-)$ & $-(-)$ & $-(-)$ & $-(-)$ & $-(-)$ & $-(-)$ & $-(-)$ & $-(-)$ & $-(-)$ & $-(-)$ & $-(-)$ & $-(-)$ & 64 (8) \\
\hline
\end{tabular}

(-): MIC not detected at up to $1024 \mu \mathrm{g} / \mathrm{mL}$; (): MIC of samples in the presence of PABN at $20 \mu \mathrm{g} / \mathrm{mL}$. The MIC of PAßN was $128 \mu \mathrm{g} / \mathrm{mL}$ on E. cloacae ECCI69 and > $256 \mu \mathrm{g} / \mathrm{mL}$ on other bacteria.

CHL: chloramphenicol. 
studied extracts can be considered important, notably the extracts from $P$. fernandopoina, B. obscura, $V$. soyauxii and $P$. staudtii leaves. When analysing the MIC and MBC results for the crude extract, MBC/MIC ratios lower than 4 were noted with most of the studied samples, suggesting that their killing effects could be expected. Therefore, the extract from $B$. obscura displayed in many cases, a bacteriostatic effect $(\mathrm{MBC} / \mathrm{MIC}>4)$ [49]. To the best of our knowledge, the antibacterial activity of the plant extracts used is being reported herein for the first time, particularly towards MDR bacteria. Nevertheless, the antimicrobial potentials of the related genus for the most active plants have been demonstrated, particularly those of genus Beilschmiedia. Chouna et al. [50] demonstrated that compounds like beilschmiedic acid $C$ from $B$. anacardioides were significantly active against Bacillus subtilis, Micrococcus luteus and Streptococcus faecalis. Beilschmiedia cinnamomea was previously demonstrated to have significant to moderate activities $(64-1024 \mu \mathrm{g} / \mathrm{mL})$ against the tested MDR bacteria [39]. Some compounds previously isolated from the genus Beilschmiedia and belonging to alkaloids, phenols, saponines, sterols and triterpenoids [50-52] were reported to possess antimicrobial activities [53]. The genus Beilschmiedia is also known traditionally to possess antimicrobial activities [53]. The fruits of B. obscura used herein are also used as soup ingredient in Cameroun [54]. This highlights its importance in the control of microbial infections and mostly those involving MDR phenotypes. Compounds belonging to alkaloids, flavonoids, sterols and triterpenoids classes previously isolated from $P$. staudtii [21-25] may be responsible for their observed activities. Bioactive alkaloids like araliopsin were previously isolated from $V$. soyauxii [17].

To assess the implication of efflux pumps in the susceptibility of Gram-negative bacteria to the tested plant extracts, PA $\beta N$ a potent inhibitor of RND efflux systems and particularly active on AcrAB-TolC (of Enterobaceriaceae) and MexAB-OprM (of Pseudomonas species) [8,55] has been used at a concentration of $20 \mu \mathrm{g} / \mathrm{mL}$. This concentration had no intrinsic effect on the bacteria as previously determined $[46,56]$. A significant increase of the antibacterial activities of the extract from P. staudtii and $B$. obscura was observed against resistant bacteria $K$. pneumoniae Kp55 strain, showing that one or more active compounds present in these plant extracts could be substrate(s) of efflux pumps of this bacteria. However, little or no increase of activities observed with the remaining extracts in the presence of EPI may be an indication that either secondary metabolites of these extracts are not active against the studied bacteria or that RND efflux pumps are not the main resistance mechanisms involved. The tested bacteria are good models in investigating MDR as they expressed active efflux pumps as observed when choramphenicol was tested in the presence of $\mathrm{PA} \beta \mathrm{N}$.

\section{Conclusions}

The investigation provided informative data for the use of the crude medicinal plant extracts tested, especially those from Beilschmiedia obscura, Peperomia fernandopoiana and Pachypodanthium staudtii in the fight against MDR bacteria. The isolation of active constituents from these plants will further be performed in order to identify their active antibacterial ingredients.

\section{Competing interests}

The authors declare that they have no competing interests.

\section{Authors' contributions}

AGF carried out the study; VK designed the experiments. AGF and VK wrote the manuscript; VK and JRK supervised the work; VK provided the bacterial strains; all authors read and approved the final manuscript.

\section{Acknowledgements}

Authors are thankful to the Cameroon National Herbarium (Yaounde) for plants identification.

Received: 14 March 2014 Accepted: 11 July 2014

Published: 14 July 2014

\section{References}

1. Blot S, Depuydt P, Vandewoude K, De Bacquer D: Measuring the impact of multidrug resistance in nosocomial infection. Curr Opin Infect Dis 2007, 20:391-396.

2. Rice LB: The clinical consequences of antimicrobial resistance. Curr Opin Microbiol 2006, 12:476-481.

3. Gandhi TN, DePestel DD, Collins CD, Nagel J, Washer LL: Managing antimicrobial resistance inintensive care units. Crit Care Med 2010, 38(8 Suppl):S315-S323.

4. Falagas ME, Bliziotis IA: Pan drug-resistant Gram-negative bacteria: the dawn of the post-antibiotic era? Int J Antimicrob Agents 2007, 29:630-636.

5. Li XZ, Nikaido H: Efflux-mediated drug resistance in bacteria: an update. Drugs 2009, 69:1555-1623.

6. Pagès JM, Alibert-Franco S, Mahamoud A, Bolla JM, Davin-Regli A, Chevalier J, Garnotel E: Efflux pumps of gram-negative bacteria, a new target for new molecules. Curr Top Med Chem 2010, 8:1848-1857.

7. Lomovskaya O, Watkins W: "Inhibition of efflux pumps as a novel approach to combat drug resistance in bacteria". J Mol Microbiol Biotechnol 2001, 3(2):225-236

8. Pagès J-M, Amaral L: Mechanisms of drug efflux and strategies to combat them: challenging the efflux pump of Gram-negative bacteria. Biochim Biophys Acta 2008, 1794:826-833.

9. Stavri M, Piddock L, Gibbons S: Bacterial efflux pump inhibitors from natural sources. J Antimicrob Chemother 2007, 59:1247-1260.

10. Cowan MM: Plant products as antimicrobial agents. Clin Microbiol Rev 1999, 12:564-582.

11. Kuete V: Potential of Cameroonian plants and derived-products against microbial infections: A review. Planta Med 2010, 76:1479-1491.

12. Maiyo ZC, Ngure RM, Matasyoh JC, Chepkorir R: Phytochemical constituents and antimicrobial activity of leaf extracts of three Amaranthus plant species. Afr J Biotechnol 2010, 9:3178-3182.

13. Adjanohoun EJ, Aboubakar N, Dramane K, Ebot ME, Ekpere JA, Enow-Orock EG, Focho D, Gbilé ZO, Kamanyi A, Kamsu Kom J, Keita A, Mbenkum T, Mbi CN, Mbiele AL, Mbome IL, Mubiru NK, Nancy WL, Nkongmeneck B, Satabie B, Sofowora A, Tamze V, Wirmum CK. Contribution to ethnobotanical and floristic studies in Cameroon. In Scientific Technical and Research Commission/Organization of African Unity, Cameroon. 1996.

14. Noumi E: Treating fibromyoma with herbal medicines in South Cameroon. Indian J Tradit Know 2010, 9(4):736-741.

15. Momeni J, Ntchatchoua WPDD, Fadimatou F, Akam MT, Ngassoum MB: Antioxidant activities of some cameroonian plants extracts used in the treatment of intestinal and infectious diseases. Indian J Pharm Sci 2010, 72(1):140-144 
16. Ikpeme EV, Ekaluo UB, Udensi OU, Ekerette EE: Potential effect of some local antimalarial herbs on reproductive functions of male albino rat. Indian J Pharm Sci 2013, 3(4):742-751.

17. Vaquette J, Hifnawy MS, Pousset IL, Fournet A, Bouquet A, Cavé A: Alcaloides d'Araliopsis soyauxii. Isolement d'un nouvel alcaloide, I'araliopsine. Phytochemistry 1976, 15:743-145.

18. Irvine FR: Woody plants of Ghana. London: Oxford University Press; 1961:6.

19. Kerharo J, Bouquet A: Plantes médicinales et toxiques de la Côte d'Ivoire Haute Volta. In Mission d'étude de la pharmacopée indigène en A.O.F. Paris: Vogot Frères; 1950:250

20. Bouquet A, Debray M: Plantes médicinales de Côte d'Ivoire. In Mission d'étude de la pharmacopée indigène en A.O.F. Edited by Mission O.R.S.T.O.M 32 ème. Paris: Vogot Frères; 1974:232.

21. Ngadjui BT, Lontsi D, Ayafor JF, Sondengam BL: Pachypophyllin and pachypostaudins A and B: three bisnorlignans from Pachypodanthium staudtii. Phytochemistry 1989, 28:231-234.

22. Bévalot F, Leboeuf M, Cavé A: La pachypodanthine, nouvel alcaloide aporphinique du Pachypodanthium staudtii Engl. et Diels, Annonacées. CR Acad Sci Paris 1976, 282:865-866.

23. Bévalot $F$, Leboeuf $M$, Cavé $A$ : Le pachysontol, composé aromatique nouveau extrait du Pachypodanthium staudtii Engl. et Diels, Annonacées. CR Acad Sci Paris 1978, 286:405-408.

24. Cavé A, Kunesh N, Leboeuf M, Bévalot F, Chiaroni A, Riche C: Alcaloides des annonacees XXV: la staudine, nouvel alcaloide isoquinoleique du Pachypodanthium staudtii Engl. et Diels. J Nat Prod 1980, 43:203-211.

25. Yapi TA, Boti JB, Félix TZ, Ahibo AC, Tomi F, Bighelli A: Pachypodanthium Staudtii Engl \& Diels from Côte d'Ivoire: composition of leaf, stem bark and roots oils. Eur J Sci Res 2012, 69(1):137-142.

26. Koona P, Koona OES: Testing fractionated extracts gained from the ethnobotanical Pachypodanthium Staudtii (Annonaceae) for bruchid insect control (Coleoptera: Bruchidae). Res J Agric \& Biol Sci 2006 2(6):410-414.

27. Ngadjui BT, Ayafor JF, Lontsi D: Unusual norlignans and antiviral agents from Pachypodanthium staudtii. Fitoterapia 1987, 56:340-341.

28. IwU MM: Handbook of Africa medicinal plants. Ann Arbor Florida USA: C.R.C. Press Boca Raton; 1993

29. Adebayo AG: Inventory of antidiabetic plants in selected districts of Lagos State, Nigeria. J Ethnopharmacol 2009, 121:135-139.

30. Adebooye OC: In Solanecio biafrae (Oliv. \& Hiern). Edited by Jeffrey C, Grubben GJH, Denton OA. Wageningen, Netherlands: PROTA 2: Vegetables/ Legumes; 2004.

31. Lienou LL, Telefo PB, Bayala BR, Yemele MD, Lemfack MC, Mouokeu C, Goka CS, Tagne SR, Moundipa FP: Ethnopharmacological survey of plants used for the treatment of female infertility in Baham, Cameroon. J Ethnopharmacol 2010, 136:178-187.

32. Focho DA, Nkeng EAP, Lucha CF, Ndam WT, Afegenui A: Ethnobotanical survey of plants used to treat diseases of the reproductive system and preliminary phytochemical screening of some species of malvaceae in Ndop Central Sub-division, Cameroon. J Medic Plant Res 2009, 3:301-314

33. Tabopda TK, Fotso GW, Ngoupayo J, Mitaine-Offer AC, Ngadjui BT, Lacaille-Dubois MA: Antimicrobial dihydroisocoumarins from Crassocephalum biafrae. Planta Med 2009, 75(11):1258-1261.

34. Lienou LL, Telefo PB, Bayala BR, Yemele D, Tagne SR, Goka CS, Lemfack MC, Mouokeu C, Moundipa FP: Effect of the aqueous extract of Senecio biafrae (Oliv. \& Hiern) J. Moore on sexual maturation of immature female rat. BMC Complement Altern Med 2012, 12:36.

35. Do Céude Madureira M, Martins AP, Gomes M, Paiva J, Proenc A, Cunha D, Do Rosario V: Antimalarial activity of medicinal plants used in traditional medicine in Sao Tome and Principe islands. J Ethnopharmacol 2002, 81:23-29.

36. Je H: Drug-resistant malaria. Trends Parasitol 2005, 21(11):494-498.

37. Lenta BN, Chouna JR, Nkeng-Efouet PA, Fon KS, Tsamo E, Sewald N: Obscurine, a new cyclostachine acid derivative from Beilschmiedia obscura. Nat Prod Commun 2011, 6(11):1591-1592.

38. Harbone JB: Phytochemical methods: a guide to modern techniques of plant analysis. London: Chapman \& Hall; 1973.

39. Fankam A, Kuete V, Voukeng Kl, Kuiate J-R, Pages J-M: Antibacterial activities of selected Cameroonian spices and their synergistic effects with antibiotics against multidrug-resistant phenotypes. BMC Complement Altern Med 2011, 11:104.
40. Seukep AJ, Fankam AG, Djeussi DE, Voukeng KI, Tankeo SB, Noumdem KAJ, Nkuete HLA, Kuete V: Antibacterial activities of the methanol extracts of seven Cameroonian dietary plants against bacteria expressing MDR phenotypes. Springer Plus 2013, 2:363.

41. Eloff JN: A sensitive and quick microplate method to determine the minimal inhibitory concentration of plant extracts for bacteria. Planta Med 1998, 64:711-713.

42. Mativandlela SPN, Lall N, Meyer JJM: Antibacterial, antifungal and antitubercular activity of Pelargonium reniforme (CURT) and Pelargonium sidoides (DC) (Geraniaceae) root extracts. S Afr J Bot 2006, 72:232-237.

43. Kuete V, Ngameni B, Simo CCF, Tankeu RK, Ngadjui BT, Meyer JJM, Lall N, Kuiate JR: Antimicrobial activity of the crude extracts and compounds from Ficus chlamydocarpa and Ficus cordata (Moraceae). J Ethnopharmacol 2008, 120:17-24.

44. Cohen MA, Huband MD, Yoder SL, Gage JW, Roland GE: Bacterial eradication by clinafloxacin, $\mathrm{Cl}-990$, and ciprofloxacin employing $\mathrm{MBC}$ test, in-vitro time-kill and in-vivo time-kill studies. J Antimicrob Chemother 1998, 41:605-614.

45. Zgoda JR, Porter JR: A convenient microdilution method screening natural products against bacteria and fungi. Pharmaceut Biol 2001 39:221-225.

46. Ghisalberti D, Masi M, Pagès J-M, Chevalier J: Chloramphenicol and expression of multidrug efflux pump in Enterobacter aerogenes. Biochem Biophys Res Commun 2005, 328:1113-1118.

47. Simões M, Bennett RN, Rosa EA: Understanding antimicrobial activities of phytochemicals against multidrug resistant bacteria and biofilms. Nat Prod Rep 2009, 26:746-757.

48. Fabry W, Okemo PO, Ansorg R: Antibacterial activity of East African medicinal plants. J Ethnopharmacol 1998, 60:79-84.

49. Carbonnelle B, Denis F, Marmonier A, Pinon G, Vague R: Bactériologie médicale: Techniques usuelles. Paris: SIMEP; 1987.

50. Chouna JR, Nkeng-Efouet PA, Lenta BN, Devkota PK, Neumann B, Stammler HG, Kimbu SF, Sewald N: Antibacterial endiandric acid derivatives from Beilschmiedia anacardioides. Phytochemistry 2009, 70:684-688.

51. Chen JJ, Chou ET, Duh CY, Yang SZ, Chen IS: New cytotoxic tatrahydrofuran and dihydrofuran-type lignans from the stem of Beilschmiedia tsangii. Planta Med 2006, 72:351-357.

52. Chen JJ, Chou ET, Peng CF, Chen IS, Yang SZ, Huang HY: Novel epoxyfuranoid lignans and antitubercular constituents from the leaves of Beilschmiedia tsangii. Planta Med 2007, 73:567-571.

53. Nkeng-Efouet PA: Phytochemicals from Beilschmiedia anacardioides and Their Biological Significance, Phytochemicals - A Global Perspective of Their Role in Nutrition and Health. In Tech. Edited by Venketeshwer $\mathrm{R}$ 2012.

54. Dibong SD, Mpondo ME, Ngoye A: Vulnérabilité des espèces à fruits sauvages vendus dans les marchés de Douala (Cameroun). J Anim Plant Sci 2011, 11(3):1435-1441.

55. Lomovskaya O, Bostian KA: Practical applications and feasibility of efflux pump inhibitors in the clinic-a vision for applied use. Biochem Pharmacol 2006, 71:910-918.

56. Lorenzi V, Muselli A, Bernardini AF, Berti L, Pagès JM, Amaral L, Bolla JM: Geraniol restores antibiotic activities against multidrug-resistant isolate from Gram-negative species. Antimicrob Agents Chemother 2009, 53:2209-2211

doi:10.1186/1472-6882-14-241

Cite this article as: Fankam et al: Antibacterial activities of Beilschmiedia obscura and six other Cameroonian medicinal plants against multi-drug resistant Gram-negative phenotypes. BMC Complementary and Alternative Medicine 2014 14:241. 